\title{
Beyond Consumerism: Reflections on Gender Politics, Pleasure and Sustainable Consumption
}

By Kate Soper

movements for gender and sexual emancipation have removed social oppressions. But they have done little to date to challenge the consumerist model of the 'good life' that is responsible for global warming, and have even reinforced its hold in certain respects. Freedom from domesticity and the patriarchal division of labour has not led - as many feminists had hoped it would - to greener and fairer ways of thinking about human prosperity, but has gone together with increased commodification and the expansion of the 'shopping mall' culture. This essay reflects on these tensions and reviews the aims and achievements of gender and environmental politics in the light of them. But it also argues that western societies are now entering a cultural moment characterised by a more troubled relationship to unchecked consumption. The upshot is the emergence of consumption as a site of new forms of political engagement, ethical consideration and aes- 
thetic representation. The 'alternative hedonism' implicit in these forms of consumer ambivalence is presented in this context as the impulse behind a new 'political imaginary' that could help to promote a fairer, environmentally sustainable and more enjoyable future - and thus fulfil some of the more radical aspirations that have been associated with the movements for gender and sexual emancipation.

\section{GENDER POLITICS AND MARKET SOCIETY}

Any thinking about gender and climate change needs to address a key tension at the heart of the globalised economy, namely, that the consumer culture on which it depends, although closely associated with 'freedom and democracy', is precipitating ecological collapse. What has helped to advance gender and sexual emancipation has also been the vehicle of unsustainable modes of consumption. The 'cultural revolution' achieved by Western feminism, for example, has been remarkable (Coward 1999), but it has coincided with the huge expansion of the shopping-mall culture. It has not unsettled the presiding structures and institutions of economic power.

On the contrary, movements for sexual emancipation have been co-opted by the market, with 'Third Wave' feminism and 'girl power' providing the springboard for all sorts of consumer oriented media interventions, brand development and advertising spin. ${ }^{1}$ More generally, with the move from a modernist, and foundationalist, to a postmodernist, and anti-foundationalist/ Foucaultian, frame of thinking about sexual difference and freedom, so there was a shift from an older style social movement politics to 'identity politics'. With that shift have come ways of thinking about selfhood, self-expression, the body, gender 'bending' and 'performance', that have encouraged a culture of 'tribalism' and selfstyling rather than the forms of solidarity that had been rooted in an earlier socialistfeminist politics. 'Identity politics' undeniably offered an important counter to the Eurocentric and essentialising conflations of social and sexual differences of an earlier moment on the Left. My point is simply that it went together with a shift of political project, away from any Marxist/socialist agenda and economic critique to an altogether more pluralist and sceptical conception of social change.

\section{FEMINISATION OF CONSUMPTION}

In a further twist to this story, we might note that in cultural studies the advance of feminism brought to attention, but did rather little to transform, the longstanding feminization of consumption - an aspect of the link that Andreas Huyssen first brought to attention in his formula 'mass culture as woman' (Huyssen 1987:47). Theorists in the academy, although often critical of the implied disparagement of women by their association with shopping as opposed to 'higher' forms of cultural activity, tended on the whole to counter that disdain, not by challenging the elision itself between femininity and consumption, but by recasting it as a form of female empowerment. The tendency in the 1980s-1990s was to celebrate the licence given to self-making, gender performance and the re-construction of identity by consumer culture rather than to criticize its forms of hedonism, or issue cautions about its social and ecological exploitations (Littler 2009:171-187; cf. Littler 2008; McRobbie 2008; Bowlby 1985, 1993; de Grazie and Furlough 1996; Nava 1992, 1996; Radner 1995).

In this process, an ongoing history of female counter-consumerist activism was ignored or downplayed, namely, the important role that women have played in various boycotts or buycotts. Or where that activity was recognised as speaking to a rather different - and more politically contestatory female role in consumption, it was criticised 
for its unreconstructed view of women as mothers and homemakers - in other words, for its reliance upon an essentialist conception of female nature as inherently suited to domestic and nurturing tasks. The emphasis on empowerment also encouraged complacency about what has actually been going on in the world of shopping - where marketing of gender stereotypes, albeit now in a mildly ironised form, has relied on sweatshop labour and continued to bring in massive profits. The fashion industry, for example, through its provision of an endless variety of very cheap clothing has persuaded many women into hyper-consumerist and throwaway dress habits. New fashion lines in shoes and other items are now replaced much more rapidly than before, with the average number of articles of apparel bought by women rising from 34 to 57 per annum in the last decade (Schor 2008). Cosmetics and plastic surgery have also proved a huge growth area. More insidiously, there has been the intensive - and highly gendered - infiltration of the child's world by branding gurus and marketing experts over the same period: a brainwashing and theft of youth that would be regarded as sinisterly totalitarian were it to occur in any other context but that of the market (Boycott 2004; cf. Palmer 2006; McRobbie 2008:544-549; Schor 2004). 'Third Wave' feminists have been understandably wary of lending themselves to the puritan or sexually repressive element that lurks in some of the critiques of these forms of commercialism. But this reluctance has meant that feminist cultural theory has been resistant to making the links between consumption and the green agenda, and done little to associate feminism with critique of the growth model of the economy. ${ }^{2}$

It would, however, be silly to imply in any attack on feminism's recent record on consumption, that it is only women and pre-teen girls who have done the consuming, or only feminist cultural theory that can be called to account. Let us not forget that most of the commodities we are talking about owe their production to companies and financial institutions in which men have retained the commanding positions, and that it is feminist theory that has exposed this gender bias in industry and its ramifications. Nor should we overlook the fact that the market in goods and services for both sexes and all age ranges has expanded relentlessly in recent decades. The enticements offered to adults, especially men - notably cars, hi-tech electronic equipment, sports goods and services - are generally much more environmentally destructive than those on offer to children. And they can be just as grotesque.

The economy has also become increasingly dependent for its 'health' on our collective preparedness to spend the money we earn by working too hard and too long on the commodities which help to compensate for the forms of need satisfaction we have increasingly sacrificed through over-work and over-production. This is a dynamic that tends to the elimination of straightforward and inexpensive forms of gratification, only then to profit further through the provision of more expensive compensatory modes of consumption for those who can afford them. The leisure and tourist industry has increasingly tailored its offerings to the overworked, with holiday breaks that promise to make good the loss in 'quality' time. Then there is the extra you often now have to pay for dealing with a person rather than a machine; the speed dating and Wife Selecting agencies that promise to make up for your loss of the arts of loving and relating; the multiplication of gyms to which people drive in order to do treadmill running in cities where, because there are so many cars on the street, they no longer find it pleasant or safe to walk or run. 


\section{COUNTERING RESPONSES}

But this focus would be misleading if it were taken to mean that there were no opposition mounting to this peculiar scenario. For Western society is now beginning to experience a more troubled relationship to unchecked consumption. Alarms over anthropogenic global warming have, of course, played a major role in this. But there have been other factors at work, many of them fuelled by the latest financial crisis. There is the anger - and anxiety many now feel about living in a world that has so plainly favoured the greed and ever more conspicuous - and environmentally vandalising - consumption of the already very wealthy, and allowed the gap between richest and poorest to grow to inflammatory proportions. To this we can add the evidence of a growing disquiet over the negative legacy of the consumerist lifestyle for consumers themselves. Today the affluent lifestyle is being brought into question not only because of its environmental consequences, but also because it distrains on both sensual pleasure and more spiritual forms of well being. We can note in this connection the many laments for what has gone missing from our lives under the relentless pressure from neo-liberal economic policies, where people often say they would prefer less tangible goods such as more free time, less stress, more personal contacts, and a slower pace of life. These voicings of discontent - many of which have a gendered narrative - are still fairly low-key, diffuse, and politically unfocussed. They are the frustrated murmurings of those who are aware of their impotence to take on the corporate giants, and have little coherent idea of what to put in place of the existing order. But their regrets are real enough, and they feed into a sense of the opportunities squandered in recent decades for enjoying more relaxed and less reductive ways of living.

This new climate of disenchantment is reflected in recent media coverage, with its concerns over the ill-health, childhood obesity, car congestion, noise, excessive waste and loss of the 'arts of living' that are the unwanted by-products of consumerism. (Schor 2004; Levett 2003; Bunting 2004; Hodgkinson 2004; Honore 2005; Shah 2005; Thomas 2008, 2009). It is registered, too, in the concerns of policy makers with the economic and social effects of the high-stress, fast-food lifestyle, and in recent studies that have indicated that buying more does not bring greater happiness, and economic growth has no direct correlation with improved levels of well-being (the New Economics Foundation 'Happy Planet' index; Lane 2001; Layard 2005; Frey and Stutzer 2002; Jackson 2004; Jackson and Marks 1999; Evans and Jackson 2007). Indeed recent research suggests that those people who have woken up to what the Sustainable Development Commission has called the 'inadequate surrogacy' of their consumerist lifestyle, and opted for less materialistic values, have gained in happiness and well-being (Brown and Kasser 2005; Kasser 2002, 2007). This is also suggested in personal reports from the 'Voluntary Simplicity' movement (www.simpleliving. net/) and the more recently formed Center for the 'New American Dream' whose mission is 'to help people live the dream, but in a way that ensures a livable planet for current and future generations' (www.newdream.org), and in the continuing expansion of the 'Slow Food' (www.slowfood.net) and 'Slow City' (www.cittaslow.net) networks.

Even those most committed to keeping us in the shopping malls, the corporate giants and their supportive governments, have come close to acknowledging their vulnerability to such 'awakenings' and the vagaries of public spending that might ensue. One already detected a sense of this, for example, in the calls following the Twin Towers attack, for us to commit to 'patriotic shopping' as a way of showing our support for the Western way of life: calls whose 
interference in our private market choices was at odds with the usual neo-liberal view of consumers as 'sovereign', and which said much about the dependency of corporate power on our continued loyalty to a consumerist way of life. And now today the idea that we have some kind of duty to spend our way out of the 'credit crisis' is being insistently repeated by politicians.

In all these ways and for all these reasons, the consumerist lifestyle is beginning to generate new tensions even within its own 'Western' heartlands, and even as it continues to offer to less wealthy nations a virtually unchallenged model of progress and human prosperity. These developments are reflected in recent academic engagement with 'political consumerism' or 'virtuous' shopping (Micheletti 2003; Micheletti and Peretti 2003; Barnett, Cloke, Clarke and Malpass 2005; Harrison, Newholm and Shaw 2005). They have also prompted new work in feminist cultural studies, notably by Jo Littler, who argues that academics now need to revisit the relations between consumption and feminism and develop a feminist response robust enough to encompass criticism of female cooption in consumer inequality and over-consumption (Littler 2009, 2008). Such arguments bear directly on my own response to the current context, which has come through the development of the concept of 'alternative hedonism', that is, the pursuit and enjoyment of other pleasures. Although I have not given this any overt gender slant, the gender implications are discernible in key aspects of its 'postconsumerist' vision, notably its challenge to a work ethic and culture rooted in the conventional gender division of labour.

\section{Alternative Hedonism}

In contrast to the mainstream responses on global warming that emphasise the technical fixes that might allow us indefinitely to pursue consumerist lifestyles, alternative he- donism dwells on the pleasures to be gained from a less work driven and acquisitive way of life. It is premised on the idea that even if consumerism were indefinitely sustainable it would not enhance human happiness and well-being, or not beyond a certain point that has already past. And it claims that it is new forms of desire rather than fears of ecological disaster that are most likely to encourage more sustainable modes of consuming. The chances of shifting to a less rapacious consumption are thus presented as dependent on the emergence and embrace of new modes of thinking about human fulfilment and the lifework balance, especially, in the first instance, on the part of the affluent global elites. A counter-consumerist ethic and politics should therefore appeal not only to compassion and environmental concern, but also to the more self-regarding gratifications of working and consuming differently. It should develop and communicate a new erotics of consumption or hedonist 'imaginary'.

By focussing on the ways in which emerging forms of disaffection with consumerism constitute an immanent critique of consumer culture, the 'alternative hedonist' perspective aims to avoid the moralising about 'real' needs that has often characterised earlier critiques of consumer culture. The concern is not to prove that consumers 'really' need something quite other than what they profess to need (or want) a procedure which is paternalistic and undemocratic - but to reflect on the hedonist aspirations prompting changes in experienced or imagined need, and their implications for the development of more sustainable modes of consumption.

This position connects with an earlier left-wing tradition of Marxist and Frankfurt School critique of commodification and 'commodity aesthetics'. Yet it differs in the attention paid to the domain of consumption as a potential source of ethical pressure and political agency. The Critical Theory 
emphasis was on the manipulation of consumer 'needs' and wants rather than on the reflexivity of consumers, and production alone was seen as the site of potential mobilisation against the capitalist order, through the agency of worker militancy. By contrast, 'alternative hedonism' argues that challenges to the status quo are more likely to be registered initially at the level of consumption - in calls for a less materially encumbered and work-driven existence. Such 'agency' would no longer be class specific, but more diffusely exercised - even if in the first instance many of the more rebellious consumers would probably be relatively well off.

\section{RETHINKING THE 'WORK/LIFE BALANCE'}

I want now, in conclusion, to turn briefly to some key aspects of the new 'political imaginary' I have associated with 'alternative hedonism', and say a word on its gender implications and how it might gain wider appeal.

What above all has to be challenged by anyone serious about a sustainable future for the planet is our general subordination to a time economy and work ethic which sees free time as a threat to prosperity rather than a form in which it can be realised. For the work-centred society does grave damage not only to the environment but also to human well-being. An unprecedented productivity that might have allowed for a more sustainable expansion of leisure, has been swallowed up in an ever expanding provision of commodities. Dramatic illustration of the opportunities missed in the US has been provided by Juliet Schor, who has argued that if Americans had settled for a 1948 standard of living (measured in terms of marketed goods and services), every worker in the United States could now be taking every other year off from work - with pay. Instead, free time fell by nearly $40 \%$ post-1973 so although the average American by 1990 owned and consumed more than twice as much as he or she did in 1948, they also had considerably less leisure (Schor 1991:2 cf. de Graaf, 2003). Similar trends are evident in the UK, where two-fifths of the workforce are now working harder than in the 1980s. The tendency, moreover, has been for the more 'workaholic' elements to set the pace for everyone else, with the threat of loss of work or promotion opportunities being used as a constant discipline against resistance to longer hours. Self-reported stress caused or made worse by work more than doubled between 1990 and 2001/2 (Bunting 2004:180). Low paid women are often particularly vulnerable (Huws 2003:7784). And it is the less well-off generally who are suffering the most dispiriting routines and practices: couples, for example, so busy they scarcely see each other all week; parents doing back to back shifts because childcare is simply proving too expensive. ${ }^{3}$ Even in areas, such as teaching, where job satisfaction in the past has to some extent compensated for relative lack of earnings, stress and insecurity have now begun to take their toll. A recent study has found an increase in depression, strain, sleep loss and unhappiness during the 1990s among Britain's six million public service workers, whose job satisfaction has now fallen dramatically. It is also those with university degrees who now report the lowest levels of job satisfaction. 4

A reduction in the working week or daily workloads, together with provision for more secure part-time employment, would significantly relieve the stress on both nature and ourselves. It would allow everyone to reap the benefits of co-parenting, and open up new ideas about personal well-being and success. A post-materialist culture would also reduce the speed at which people, goods and information had to be delivered or transmitted thus having hugely beneficial effects on resource attrition and carbon emissions. People would commute 
less and enjoy healthier modes of travel, such as walking, cycling, boating. These moves would make roads safer, transform city and rural living and offer experiences of landscape unavailable to those in cars or planes. It would also bring a return of high street retailers in place of supermarket shopping, boost local economies, help reduce crime, and foster new forms of street conviviality.

There are, of course, huge problems confronting any attempt to 'slow down' along these lines because of the integration of national economies in a pace of life determined by the dynamics of globalisation. But we now desperately need another model of development and a beginning has to be made somewhere. 5 The affluent societies of Europe and Scandinavia are well-placed to spearhead a new order and to catalyse the political will for change, and were they to take a global lead on this, they could promote an alternative model of prosperity through which the less 'developed' countries might critically reconsider the conventions and goals of 'progress' itself - and thereby better understand the worst consequences of north-west 'over-development' and how to avoid them.

\section{THE ROLE OF CULTURE AND 'AESTHETIC REVISIONING'}

An alternative cultural 'political imaginary' along these lines would involve a profound shift of values foreshadowing the ousting of monetary greed from its central place in our culture. Aesthetically, it implies a fundamental revisioning of the perceived attractions of material culture, a shift of optic and hedonist perception. I have compared this to the 'consciousness raising' brought about through Western feminism and its gradual but profound impact on our way of life. As individuals became alerted to the role of gender in their being, and to its social construction and hence mutability, so they entered into complex - and often painful - processes of self-change. A green economic and cultural renaissance working upon consumer sensibilities over coming years could result in some similar revisioning of self-interest and aesthetic response. The result would be that a lifestyle once seen as compelling comes to seem confining, and previously sought after commodities come to be viewed as cumbersome and ugly through association with unsustainable resource use, noise, toxicity or their legacy of un-recyclable waste (Soper 2008).

The revisioning in question here is not a case of 'pure' aesthetic judgement in the disinterested Kantian sense, since it is closely aligned with a general re-thinking of pleasure and the good life that would be achieved through a 'green' renaissance. If, for example, you come to know that $\mathrm{x}$ does you harm, you tend to perceive it differently. The green renaissance would harness this interdependency of belief and aesthetic experience for its own counter-consumerist purposes, and seek to extend it to the environment at large, such that goods that were unsustainable, even though not responsible for any immediate personal damage to the individual, ceased to exercise their former aesthetic compulsion.

Images of waste in the form of negative sublimes that stifle and overwhelm us with the burden of our own productions, may also have a part to play in these aesthetic shifts, since the junk excreta of consumerist society is so plainly and repellently undesirable. The move to sustainable consumption will also require - though I recognise how controversial this will sound - a more courageous challenge to the 'political incorrectness' of excessive and nonchalant consumers. It is still very difficult to criticize the environmental squandering involved in people's consumption habits and there is much embarrassment all round if one does. But faced with the oppressive effects of the climatic impact of first world affluence on other, more deprived, areas of the globe, and on all future generations, it 
is no longer clear why highly wasteful and polluting forms of personal consumption should remain exempt from the kinds of criticism that we now expect to be brought against racist or sexist or blatantly undemocratic attitudes and modes of behaviour. If we have a cosmopolitan care for the wellbeing of the more deprived people of the world, and a concern about the quality of life of future generations, we need a dramatic change of attitudes to work, consumption, pleasure and self-realisation. And such a revolution will surely be comparable in the forms of personal epiphany and transformation it will demand to those brought about through the feminist, antiracist and anti-colonialist movements of recent history.

\section{Notes}

1. 'Third Wave' is used to refer to the feminism of the 1980s onwards, to distinguish it from the 'second wave' of the 1960-70s (itself distinguished from late 19th and early 20th century 'first wave' feminism.)

2. This link has, of course, been made by eco-feminists. However, many women, myself included, are troubled by the inclination of eco-feminists to assume that women are by nature carers and have some special responsibility for the environment that men do not have. I would also question the readiness of many eco-feminists to endorse a 'back to nature ethic', rather than to think in terms of the more humanly complex and rewarding life that may be found beyond consumerism 3. A survey by Dr. Roger Henderson for the At Home Society, 2005, covering 1,074 working and co-habiting adults over the age of 18 , found that more than a fifth of couples were so busy they could go for a week without seeing each other, often with serious impact on their relationship ('All work and no play makes love drift away' in The Independent, 28th October 2005).

4. Study from Andrew Oswald and Jonathan Gardner reported in The Guardian March 22 2001 'Job Satisfaction falls for Public Workers'. 5 . And results from a simulation model of the Canadian economy suggest that it is possible to have full employment, eradicate poverty, reduce greenhouse gas emissions and maintain fiscal balance without economic growth. For further details, see the LowGrow model advocated by Peter Victor (2008) and the papers from the Sustainable Development Commission.

\section{LITERATURE}

- Barnett, Clive, Cloke, Paul, Clarke, Nick and Malpass, Alice (2005): 'Consuming ethics: Articulating the subjects and spaces of ethical consumption', in: Antipode 37,1, pp 23-45.

- Boycott, O. (2004): 'Make-up and marketing welcome to the world of 10 year old girls', in: The Guardian, $8^{\text {th }}$ September, 2004.

- Bowlby, Rachel (1985): Just Looking. Methuen.

Routledge, London.

- Bowlby, Rachel (1993): Shopping with Freud.

Routledge, London.

- Brown, K. W. and Kasser, Tim (2005): 'Are psychological and ecological well-being compatible? The role of values, mindfulness, and lifestyle' in $\mathrm{So}^{-}$ cial Indicators Research, 74, pp.349-368.

- Bunting, Madeleine (2004): Willing Slaves: How the Overwork Culture is Ruling Our Lives. Harper Collins, London.

- Coward, Rosalind (1999): 'Do we Need a New

Feminism?' in: Women, A Cultural Review, 10, 2.

. Evans, David and Jackson, Tim (2007): 'Towards a Sociology of sustainable Lifestyles' in: RESOLVE Working Papers 03-07 (www.surrey.ac.uk/resolve).

- Frey, Bruno and Stutzer, Alois (2002): Happiness and Economics. Princeton University Press, Princeton.

- de Graaf, John (2003) (ed.): Take back your time: Fighting overwork and time poverty in America.

Berret-Koehler, San Francisco.

- de Grazie, Victoria and Furlough, Ellen (eds.) (1996): The Sex of Things: Gender and Consumption in Historical Perspective. University of California Press, Berkeley.

- Harrison, Rob, Terry Newholm and Deirdre Shaw (eds.) (2005): The Ethical Consumer. Sage, London.

. Hodgkinson, Tom (2004): How to be Idle.

Hamish Hamilton, London.

- Honore, Carl (2005): In praise of slowness: Challenging the cult of speed. Harper One, New York. - Huyssen, A. (1987): After the Great Divide: Modernism, Mass Culture and Postmodernism. Indiana University Press, Bloomington.

- Huws, Ursula (2003): The Making of a Cybertariat: virtual work in a real world. Merlin Press, London. 
· Jackson, Tim (2004): Chasing Progress: beyond measuring economic growth. New Economics Foundation, London.

· Jackson, Tim and Marks, Nic (1999): ' Consumption, Sustainable Welfare and Human Needs' in Ecological Economics 28, pp. 421-442.

- Journal of Consumer Culture (2007): Special issue on 'citizenship and consumption', 7, 2.

- Kasser, Tim (2002): The high price of materialism. MIT Press, Cambridge, MA.

- Kasser, Tim (2007): 'Values and Prosperity', paper to Sustainable Development Commission seminar on 'Visions of Prosperity', 26th November (www.sdcommission.org.uk/publications). - Lane, Robert (2001): The Loss of Happiness in Market Democracies. Yale University Press, Yale. - Layard, Richard (2005): Happiness: Lessons from a New Science. Allen Lane, London.

- Levett, Roger (2003): A Better Choice of Choice: Quality of Life, consumption and economic growth. Fabian Society, London.

- Littler, Jo (2008): Radical Consumption? Shopping for Change in Contemporary Culture. Open University Press, Milton Keynes.

- Littler, Jo (2009): 'Gendering Anti-Consumerism: Alternative Genealogies, Consumer Whores and the Role of Ressentiment', in: Soper, K., Ryle, M. and Thomas, L (eds.): The Politics and Pleasures of Consuming Differently, Palgrave, London. - McRobbie, Angela (2008): 'Young Women and Consumer Culture', in: Cultural Studies, 22, 5, pp. 531-550.

- Micheletti, Michelle (2003): Political Virtue and Shopping. Palgrave, New York and London.

- Micheletti, Michelle and Peretti, Jonah (2003):

'The Nike Sweatshop Email: Political Consumerism, Internet and Cultural Jamming', in: Michelle Micheletti et alii (eds): Politics, Products and Markets: Exploring Political Consumerism Past and Present. New Brunswick, New Jersey.

- Nava, Mica (1992): Changing Cultures: Feminism, Youth and Consumerism. Sage, London. - Nava, Mica (1996): 'Modernity's disavowal: Women, the city and the department store', in: Mica Nava and Alan O' Shea (eds): Modern Times: Reflections on a Century of English Modernity. Routledge, London.
- New Economic Foundation (2006): 'Happy Planet Index'

www.happyplanetindex.org/reveals.htm.

- Palmer, Sue (2006): Toxic Childhood. Orion,

London.

- Radner, Hilary (1995): Shopping Around: Feminine Culture and the Pursuit of Pleasures. Routledge, New York.

- Schor, Juliet (1991): The Overworked American: The Unexpected Decline of Leisure. Harper Collins, New York.

- Schor, Juliet (2004): Born to Buy, the Commercialised Child and the New Consumer Culture. Simon and Schuster, London.

- Schor, Juliet (2008): Interviewed by Jo Littler, in: Cultural Studies, 22, 5, pp. 588-598.

- Shah, Hetan (2005): 'The Politics of Well-Being', in: Soundings 30, pp. 33-44.

- Soper, Kate (2008): 'Alternative Hedonism, Cultural Theory and the Role of Aesthetic Revisioning', in: Cultural Studies, 22, 5, pp. 567-587. - Soper, Kate (2009): 'Introduction', in: Kate Soper, Martin Ryle and Lyn Thomas (eds.): The Politics and Pleasures of Consuming Differently. Palgrave, London, pp. 1-24.

- Sustainable Development Commission UK (2003): 'Redefining Prosperity, Resource Productivity, Economic Growth and Sustainable Development' (www.sdcommission.org.uk/publications). - Thomas, Lyn (2008): 'Alternative Realities: Downshifting Narratives in Contemporary Lifestyle Television', in: Cultural Studies, 22, 5, pp.680-699.

. Thomas, Lyn (2009): 'Ecochic: Green Echoes and Rural Retreats in Contemporary Lifestyle Magazines', in: Kate Soper, Martin Ryle and Lyn Thomas (eds): The Politics and Pleasures of Consuming Differently. Palgrave, London, pp.59-73. - Victor, Peter (2008): Managing without Growth. Slower by Design, not Disaster. Edward Elgar Publishing, London.

Kate Soper, Emeritus Professor of Philosophy Institute for the Study of European Transformations, London Metropolitan University and Honorary Visiting Professor at the University of Brighton 